\title{
해안지역 콘크리트 구조물의 염소이온침투특성 평가 Evaluation of Chloride Ion Penetration Characteristics for Concrete Structures at Coastal Area
}

\author{
한상훈* - 이진학** - 박우선** \\ Sang Hun Han*, Jin Hak Yi** and Woo Sun Park**
}

\begin{abstract}
요 지 : 항만콘크리트 구조물의 내구성 저하의 중요한 요인은 염소이온침투에 의한 철근의 부식이다. 따라서, 항 만콘크리트 구조물의 염소이온 깊이와 깊이별 염소이온농도를 정량적으로 파악할 수 있다면, 구조물의 잔존수명을 사전에 비교적 정확하게 평가할 수 있다. 이러한, 구조물에서의 염소이온농도를 예측하기 위해서는 모델식의 개발이 필요하고 모델식은 정확한 현장데이타를 기반으로 한다. 이에 본 연구에서는 현장 항만구조물에 대한 코어시료를 채 취하고 본 시료들에 대한 염소이온침투깊이와 깊이별 염소이온농도를 측정하고자 하였다. 시료는 1 차로 완도항, 마 산항, 인천항에서 채취하였고, 2 차로 여수항과 동해항에서 채취하였다. 수직 높이별 영향을 파악하기 위해서 대기부, 비 말대, 간만대로 나뉘어 각 층별 8 개의 시료를 획득하였다. 채취된 시료중에서 4 개는 강도 실험을 실시하였고, 나머 지 4 개로 내구성 실험을 실시하였다. 2 개의 시료에 대해서는 질산은 변색법을 이용하여 염소이온 침투깊이를 측정 하였다. 나머지 2 개의 시료는 깊이별로 $5 \mathrm{~mm}$ 두께의 절편을 채취하고 이를 ASTM C 114 의 시험법에 따라 염화 물 이온농도를 측정하였다. 측정결과를 바탕으로 지역과 수직위치에 따른 염소이온 침투의 특성을 파악하였다.
\end{abstract}

핵심용어 : 내구성, 염소이온, 해양 콘크리트, 잔존수명

\begin{abstract}
A major source of durability problems in concrete structures is the corrosion of steel by the damage of passivity layer around steel bars. As chloride ion penetration is major cause of the destruction of passivity layer, evaluation of depth and concentration profile of chloride ion is the essential factor for the service-life estimation of concrete structure. To estimate chloride ion penetration characteristics, this paper on the basis of in-situ experimental data investigated the depth and concentration profile of chloride ion penetration. The core specimens are obtained at air-zone, splash zone, and tidal zone in Wando, Masan, Incheon, Gwangyang, and donghae harbors. Colorimentric method measured the chloride ion penetration depth and ASTM C 114 evaluated the concentration profile of chloride ion. Based on experimental data, the influence of harbor location and exposure condition on chloride ion penetration is evaluated.
\end{abstract}

Keywords : Durability, chloride ion, marine concrete, servicelife

\section{1. 서 론}

해양항만구조물은 고부식성의 해양환경에 노출됨에 따라 육 상구조물에 비해 내구성 저하가 발생할 잠재적인 요인이 크다. 이 러한 항만구조물의 내구성 저하현상 중에서 가장 일반적인 것이 해수 염소이온의 콘크리트 구조물 내부로의 침투에 의한 염해이 다(Val et al., 2008). 염소이온에 콘크리트 내부로 침투하게 되 면, 철근 주위의 $\mathrm{pH}$ 를 저하시켜 철근의 부동태 피막을 파괴시킨 다. 철근의 부동태 피막이 파괴되면, 내부철근은 급속하게 부식 하게된다. 철근이 부식하면 단면팽창이 발생하고 팽창압에 의해 피복두께에 균열이 발생된다. 균열사이로 외부의 해수가 더욱 빨 리 침투됨에 따라 열화는 더욱 가속화된다(Neville, 1995).
염소이온침투에 해양항만구조물의 내구성 저하 현상을 파악 하기 위해서는 염소이온침투의 영향요인들에 대한 정량적인 평 가가 필수적이다. 깊이별 염소이온침투를 모델링하는 가장 일 반적인 모델식은 Fick의 확산방정식이다. 이 식에 의한 깊이별 염소이온농도에 큰 영향을 미치는 것들이 표면염소이온농도와 염소이온확산계수이다(한상훈 et al., 2003). 이에 대한 연구는 여러 연구자들에 의해 수행되었지만, 대부분 실내에서 만든 시 료들을 바탕으로하고 있어 현장환경조건을 재현하는데에는 한 계가 있다(김명유 2010, 박승범 et al., 2000).

본 논문에서는 주요 항만구조물에서 채취한 코어시료를 바 탕으로 깊이별 염소이온농도의 현장환경조건별 특성을 파악한 다. 또한, 실험데이타의 회귀분석을 통해 표면염소이온농도와 염

*한국해양연구원 연안개발에너지연구부 (Corresponding author : Sang Hun Han, Coastal Engineering \& Energy Depart. KORDI, Ansan P.O. Box 29, Seoul 425-600, Korea. shhan@kordi.re.kr)

**한국해양연구원 연안개발에너지연구부 (Coastal Engineering \& Energy Depart. KORDI, Ansan P.O. Box 29, Seoul 425-600, Korea.) 
소이온확산계수를 파악하여 지역별, 수직 높이별 특성을 고찰 하였다.

\section{2. 실 험}

\section{1 실험개요}

항만구조물에 대한 리모델링 기반 구축 연구의 일환으로 노후 항만구조물에 대한 현장 비파괴 실험과 코어채취를 실시하였다. 대상 항만은 마산항 제1부두(준공연도 1939년), 인천항 제2부 두(준공연도 1974년), 완도항 제2물양장(준공연도 1989년), 광 양항 중흥물양장(준공연도 1999), 동해항 남부두(준공연도 1999) 이다(Fig. 1 참조). 코어는 수직벽체에 대해서 간만대, 비말대, 대기부로 영역을 나뉘어 채취하는 것을 기본으로 하였다(Fig. 2 참조). 그러나, 인천항과 동해항은 간만대가 존재하지 않아 비 말대와 대기부에서만 시료를 채취하였다. 간만대는 평균간조위

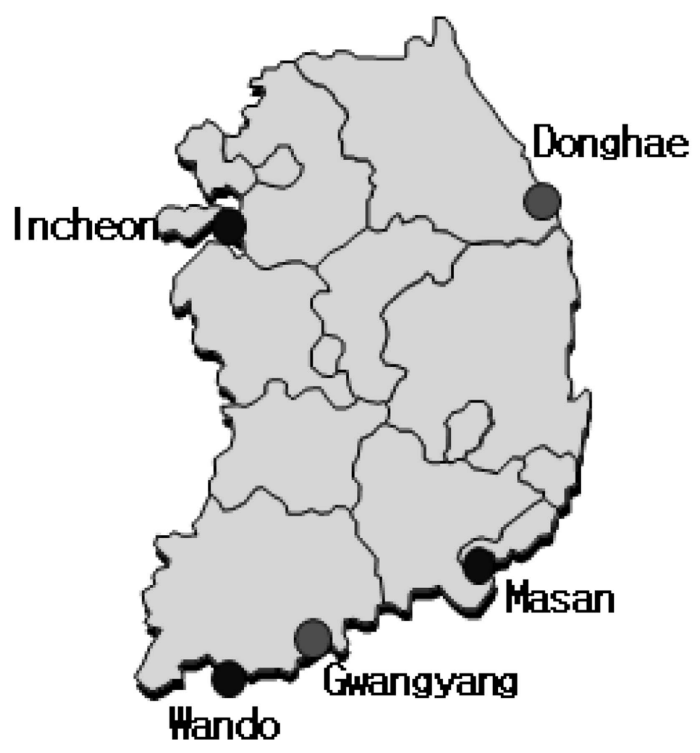

Fig. 1. Location of test harbor.

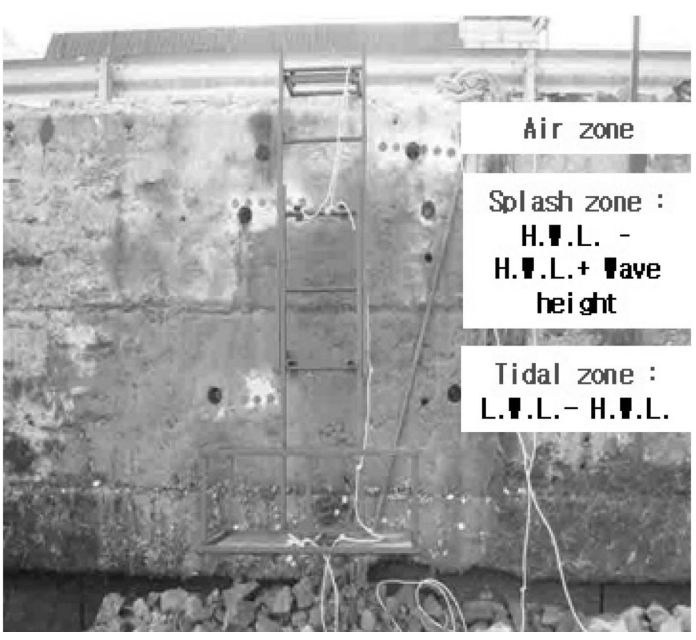

Fig. 2. Sampling location in structure.
(L.H.L.)와 평균만조위(H.W.L.)사이의 영역, 비말대는 평균만조 위와 평균만조위+파고의 영역, 대기부는 평균만조위+파고 위의 수직영역으로 정의하였다.

\section{2 실험방법}

염소이온침투 깊이는 질산은 변색법으로 측정하였고, 깊이별 염소이온농도실험는 ASTM C 114기법과 RCT법에 의한 방법을 이용하여 측정하였다(ASTM C 114, 2000; Germann Instruments, 2010). 질산은 변색법은 $\mathrm{Ag}+$ 이온과 $\mathrm{Cl}$-이온의 반응을 통하여 흰색 침전물을 형성하는 원리를 이용한 것이다(김명유, 2010). 이러한 변색법을 염화물의 침투를 받은 콘크리트에 적용하게 되 면 두 가지 반응이 발생하게 된다. 은이온이 염소이온과 결합 하면 흰색 침전물이, 수산화이온과결합하면 진갈색 침전물이 생 성되는데, 흰색침전물의 길이를 측정하면 염소이온 침투깊이를 측정할 수 있다(Fig. 3 참조).

염화물 농도 프로파일 측정은 농도 프로파일을 측정하고자 코어 시험체로부터 깊이별로 $5 \mathrm{~mm}$ 두께의 시료를 채취/분쇄하여 ASTM C 114(산가용성 염화물, 수용성 염화물 측정법)의 시험 법에 따라 염화물 이온을 추출하였다. 추출된 염화물을 선택성 전극을 사용하여 농도를 측정하였다(Fig. 4 참조). 또한, 일부 시료에 대한 총염화물량은 전위차 적정법인 ASTM C 114이 아닌 Germann Instruments사의 RCT(Rapid Chloride Test) 키트를 사용하여 측정하여 간편한 기법의 적용가능성을 평가하였다.

\section{3 실험결과}

각 항만구조물에 대한 배합설계 자료가 남아있지 않아, 시공 시에 사용한 재료의 성질을 파악할 수 없었다. 그러나, 시료를 채취했으므로 이에 대한 강도실험을 통해 각 구조물의 재료물 성을 간접적으로 추정할 수 있다. Table 1 의 강도실험결과를 살 펴보면, 완도 물양장의 압축강도 결과를 제외하고는 나머지 시 설의 강도는 $30 \mathrm{MPa}$ 내외로 유사함을 알 수 있다. 완도 물양

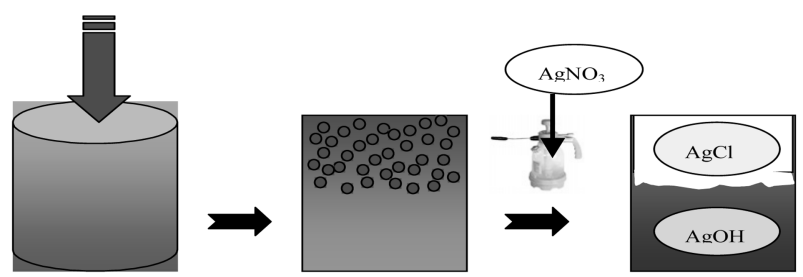

Fig. 3. Colorimetric method.

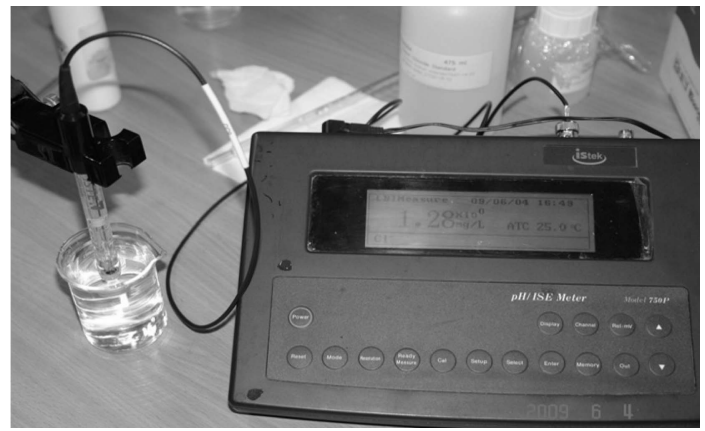

Fig. 4. Measurement of chloride ion concentration. 
Table 1. Result of compressive strength

\begin{tabular}{lcccc}
\hline & Air zone & Splash zone & Tidal zone & Average \\
\hline Masan & 42 & 28 & 31 & 34 \\
Incheon & 30 & 23 & - & 27 \\
Wando & 28 & 23 & 22 & 24 \\
Donghae & 29 & 30 & - & 30 \\
Gwangyang & 32 & 34 & 29 & 32 \\
Average (MPa) & 32 & 28 & 27 & 29 \\
\hline
\end{tabular}

장은 이 보다 조금 작은 $24 \mathrm{MPa}$ 정도이다.

질산은 변색법에 의한 결과를 살펴보면(Fig. 5), 동해항의 비 말대의 침투깊이가 가장 크고 간만대의 경우는 마산항의 경우가 가장 염소이온침투깊이가 크다. 질산은 변색법에 의한 침투깊 이가 임계염소이온농도지점에 해당된다는 연구도 있어(Otuki et al., 1992), 이러한 수준으로 염소이온이 침투된다면 철근부식의 문 제가 발생할 수 있다.

Fig. 6는 깊이별 염소이온농도를 나타낸 것이다. 대기부의 경 우에는 염소이온 침투가 얕은 영역에서 0 으로 수렴하고 반면 에 비말대는 긴 영역에 걸쳐 염소이온농도가 높은 수준을 유 지함을 관찰할 수 있다. 즉, 깊은영역까지 염소이온 침투가 진 행되었을 추측할 수 있다. 완도항과 광양항의 대기부 실험결과 의 경우에는 $20-30 \mathrm{~mm}$ 의 깊이에서 염소이온농도의 최고점이 나
Table 2. Ratio of total and free chloride concentration

\begin{tabular}{lcccc}
\hline \hline & Air zone & Splash zone & Tidal zone & Average \\
\hline Masan & 0.50 & 0.52 & 0.52 & 0.51 \\
Incheon & 0.74 & 0.51 & - & 0.63 \\
Wando & 0.46 & 0.55 & 0.50 & 0.50 \\
Donghae & 0.69 & 0.49 & - & 0.59 \\
Gwangyang & 0.78 & 0.61 & 0.66 & 0.68 \\
Average & 0.63 & 0.54 & 0.56 & 0.58 \\
\hline
\end{tabular}

타나는데 이것은 탄산화와 염소이온침투가 동시에 진행되어 나 타난 현상일 수 있다(이상민 et al., 2009). 지역별, 수직높이별 염소이온침투특성에 대한 내용은 현재의 실험결과를 분석한 다 음장에서 다루고자 한다.

Table 2 는 자유염소이온농도와 총염소이온농도의 비를 지역 별, 수직 위치별로 비교하고 있다. 항만의 위치에 따라서 두 값의 비는 0.50 에서 0.68 사이이고, 수직위치별로는 0.54 에서 0.63 사 이이다. 염소이온농도에 대한 실험값의 변동성을 고려할 때, 지 역별, 수직위치별 자유염소이온농도와 총염소이온농도의 비는 큰 차이가 없는 것으로 판단된다. 한편, 최근에 김명유(2010)는 자신의 실험결과를 바탕으로 자유염소이온농도와 고정염소이온 농도의 상관관계를 회귀분석하여 선형모델이 가장 적합한 모델 로 제시하고 기울기를 0.85 로 제시하였다. 이를 자유염소이온

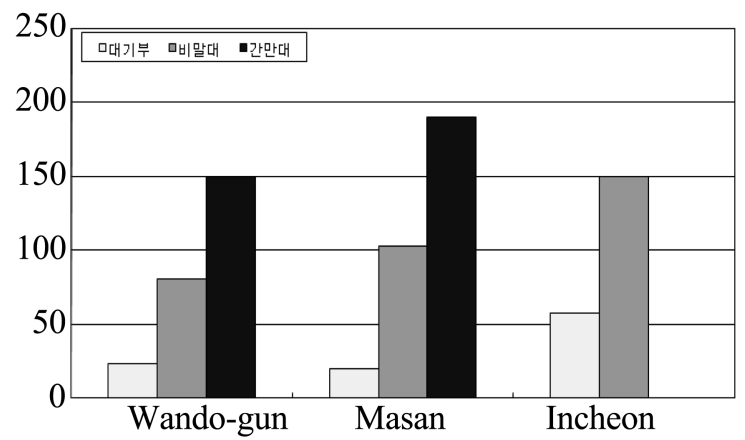

(a) 1st test (2009)

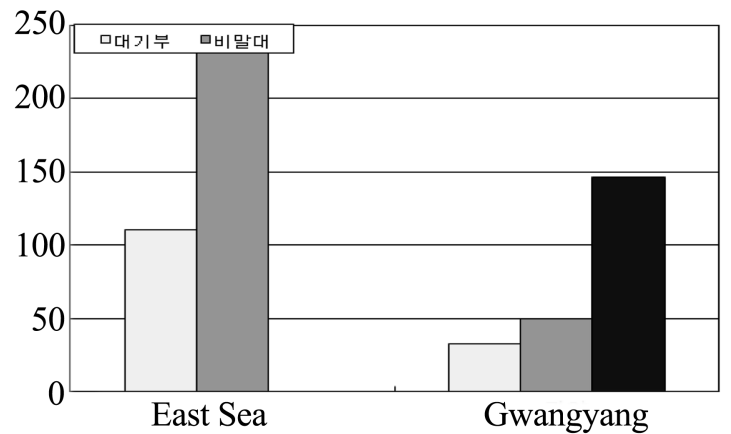

(b) 2nd test (2010)

Fig. 5. Result of colorimetric method.

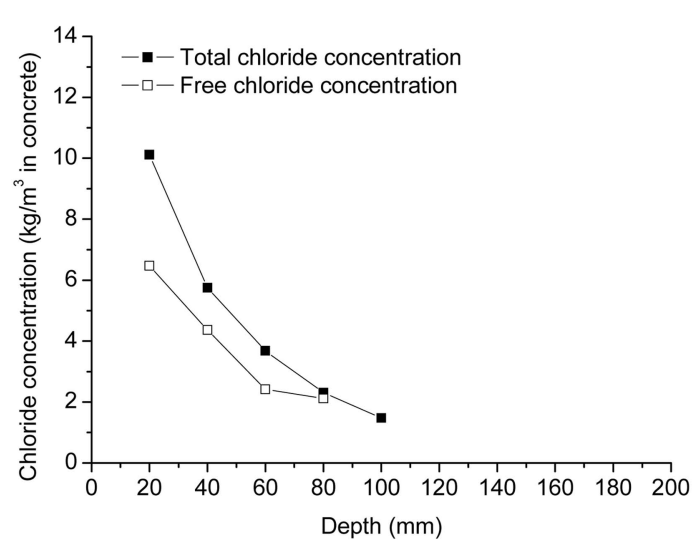

(a) Air zone - Incheon

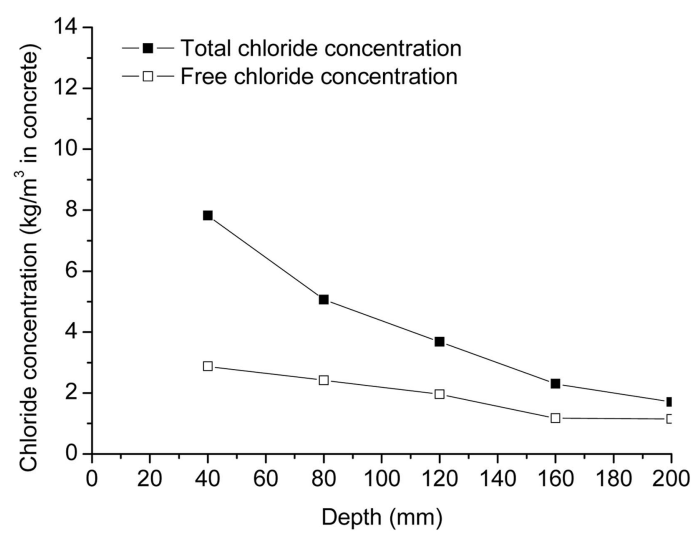

(b) Splash zone - Incheon

Fig. 6. Profiles of chloride ion. 


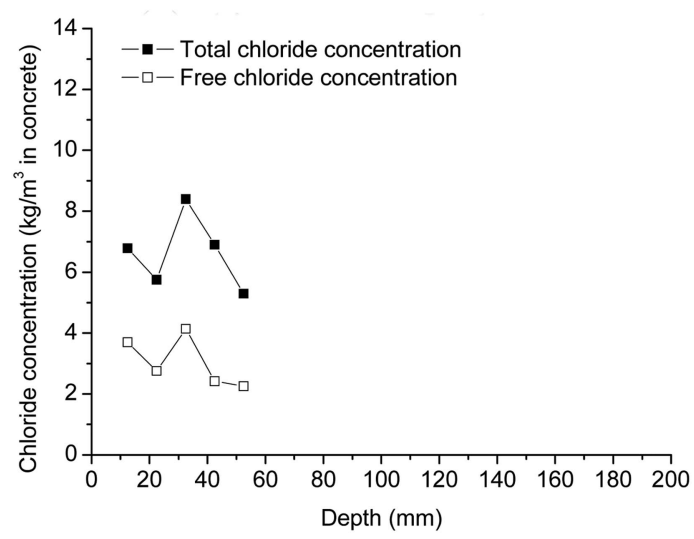

(c) Air zone - Wando

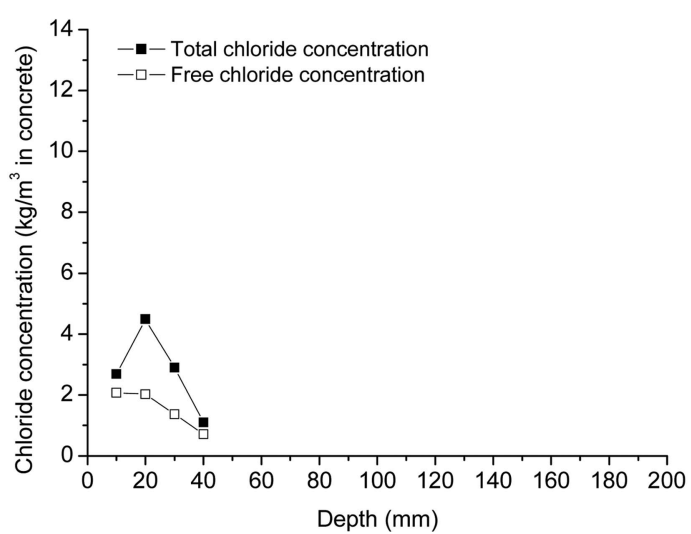

(e) Air zone - Gwangyang

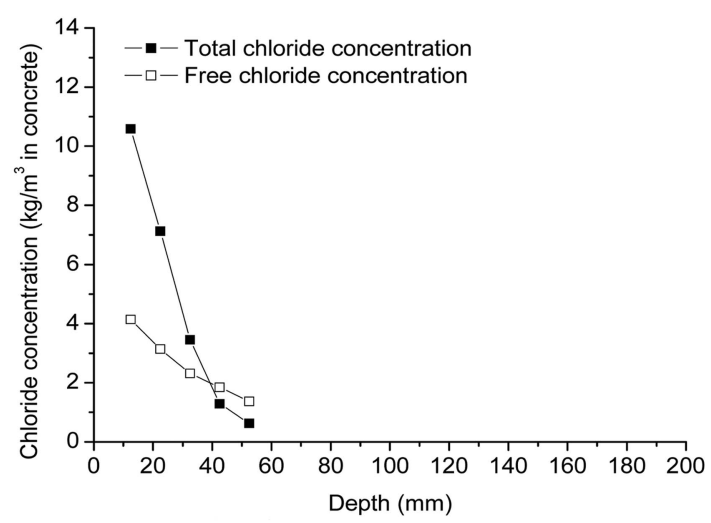

(g) Air zone - Masan

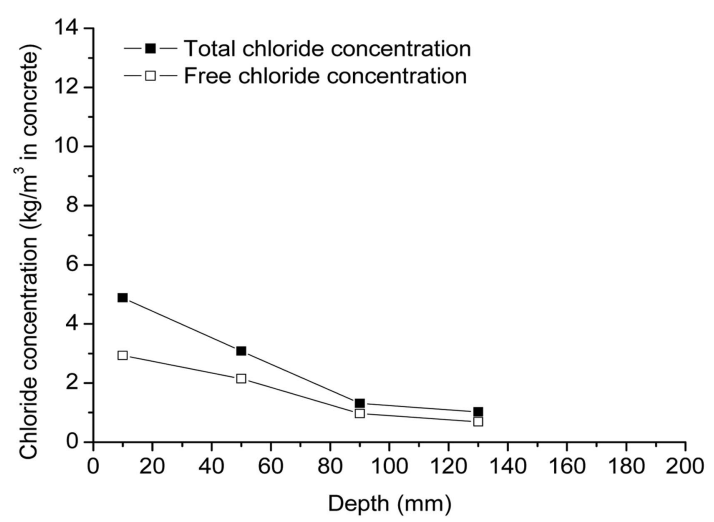

(i) Air zone - Donghae

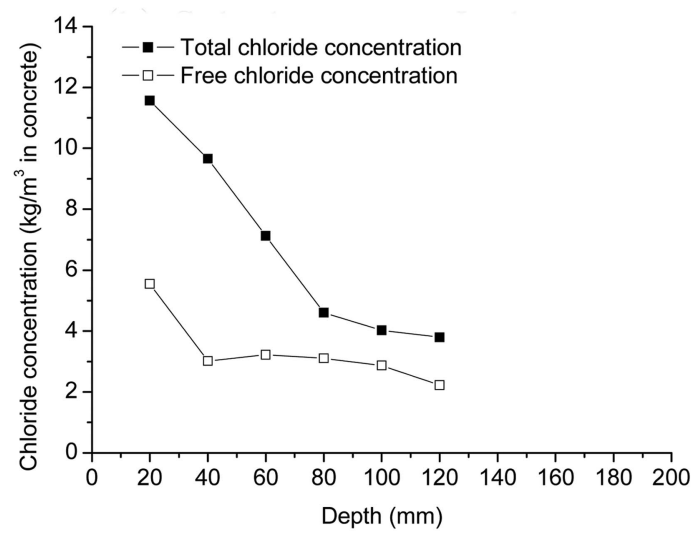

(d) Splash zone - Wando

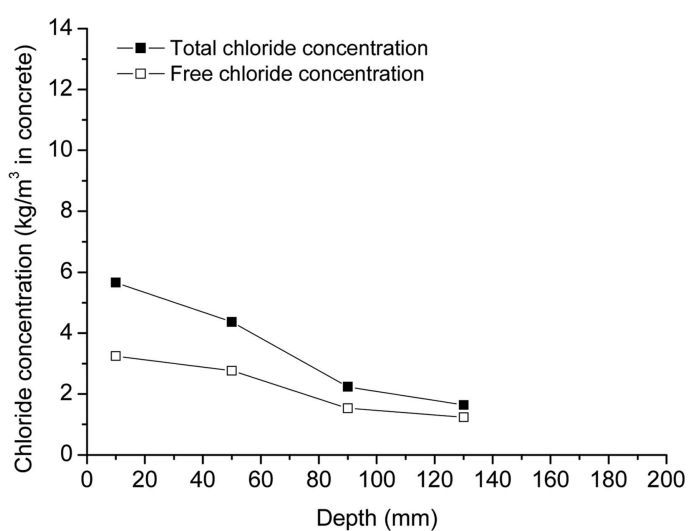

(f) Splash zone - Gwangyang

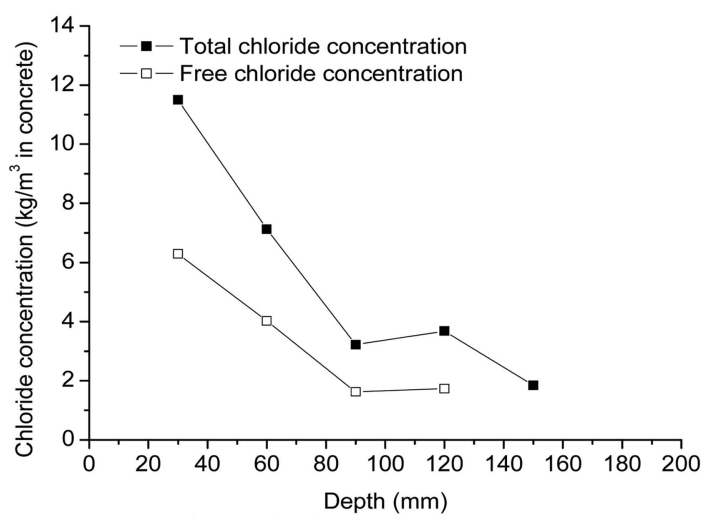

(h) Splash zone - Masan

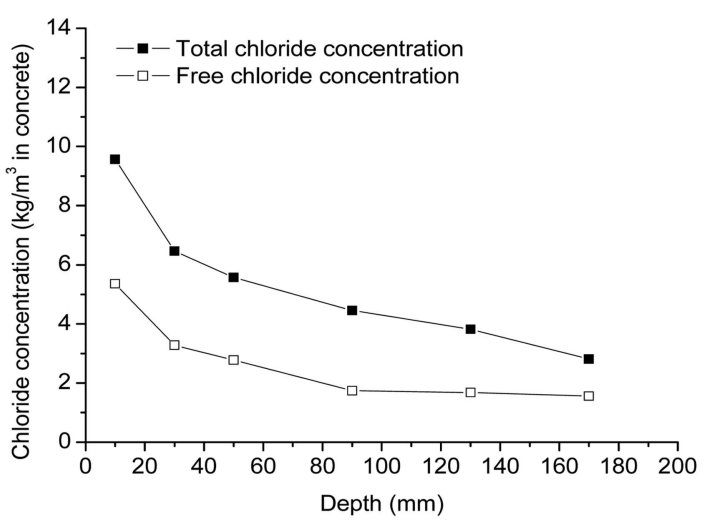

(j) Shlash zone - Donghae

Fig. 6. Continued. 


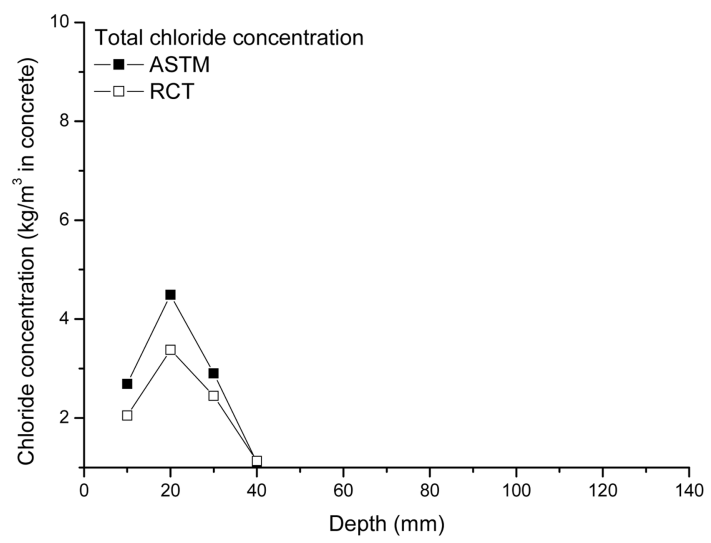

(a) Air zone

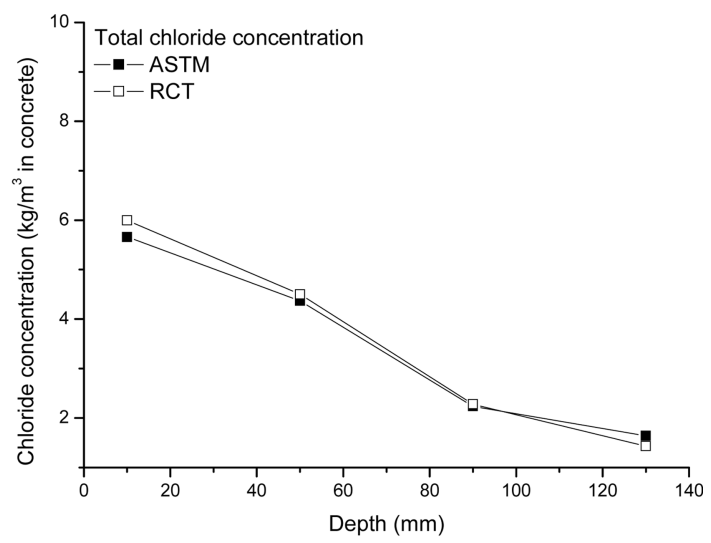

(b) Tidal zone

Fig. 7. Comparison of experimental methods (Gwangyang).

농도와 총염소이온농도의 비로 환산하면 0.54 이다. 이것은 본 논문의 0.58 과 거의 유사한 값이다.

\section{3. 분 석}

\section{1 실험법에 따른 염소이온농도}

일반적인 전위차 적정법인 ASTM C 114 시험법은 시간과 노력이 많이 소요된다. 반면에 Germann Instruments사의 RCT 시스템은 빠른 실험이 가능하여 현장에서도 적용이 가능하다. 이에 본 연구에서는 ASTM C 114 시험법과 RCT법을 모두 적 용하여 총염화물량을 측정하여 RCT법의 적용성을 살펴보았다. 광양과 동해에서의 시료들에 대한 두 시험법에 의한 차이는 Table 3과 같다.

거의 모든 실험결과에서 $\mathrm{RCT}$ 법에 의한 염소이온농도가 ASTM C 114 시험법에 의한 염소이온농도보다 작았다. 이것은 $\mathrm{RCT}$ 법에 의한 실험에서는 시료속의 염소이온이 충분히 용출 되지 않아서 발생한 것으로 판단된다. 수직영역에 따라서도 두 값의 차이가 났는데, 비말대에서 가장 차이가 크고 간만대가 차 이가 가장 작았다. $10 \mathrm{~mm}$ 에서 $130 \mathrm{~mm}$ 까지의 깊이별 실험법에

Table 3. Ratio of chloride ion concentration by RCT and ASTM

\begin{tabular}{ccccccc}
\hline \hline & \multicolumn{3}{c}{ Gwangyang } & \multicolumn{3}{c}{ Donghae } \\
\cline { 2 - 6 } $\begin{array}{c}\text { Depth } \\
(\mathrm{mm})\end{array}$ & $\begin{array}{c}\text { Air } \\
\text { zone } \\
(\%)\end{array}$ & $\begin{array}{c}\text { Splash } \\
\text { zone } \\
(\%)\end{array}$ & $\begin{array}{c}\text { Tidal } \\
\text { zone } \\
(\%)\end{array}$ & $\begin{array}{c}\text { Air } \\
\text { zone } \\
(\%)\end{array}$ & $\begin{array}{c}\text { Splash } \\
\text { zone } \\
(\%)\end{array}$ & $\begin{array}{c}\text { Average } \\
(\%)\end{array}$ \\
\hline 10 & -23.8 & -12.7 & 6.0 & -25.7 & -56.4 & -22.5 \\
20 & -24.7 & -28.9 & & & & -26.8 \\
30 & -15.5 & -30.6 & & & -59.8 & -35.3 \\
40 & 1.9 & -21.6 & & & & -9.8 \\
50 & & & 3.0 & -26.2 & -59.1 & -27.4 \\
90 & & & 1.3 & -22.5 & -54.1 & -25.1 \\
130 & & & -13.3 & -24.3 & -53.5 & -30.3 \\
Average $(\%)$ & -15.5 & -23.4 & -0.7 & -24.6 & -56.5 & -25.3 \\
\hline
\end{tabular}

*Ratio (\%) = (RCT data - ASTM data)/ASTM data
의한 염소이온농도의 차이는 뚜렷하지 않았다.

전체데이타를 기준으로 평균한 두 실험법의 염소이온농도차 이는 $25 \%$ 정도이다. 즉, $\mathrm{RCT}$ 법에 의해 측정된 염소이온농도에 1.33 배를 하면 전위차 적정법과 유사한 결과를 나타낼 수 있다. 그러나, 현재의 데이터만으로 두 실험법의 차이를 확정할 수는 없다. Germann Instruments사에서 제시하는 실내실험의 결과는 $\mathrm{RCT}$ 법에 의한 염소이온농도와 ASTM C 114 시험법에 의한 염소이온농도가 유사하기 때문이다. 이에 대해서는 향후 지속 적인 연구가 필요할 것으로 판단된다.

\section{2 표면염소이온농도}

실험을 통해 시료의 깊이별 염소이온농도를 구하면, 다음과 같은 Fick의 확산모델에 대한 일반해를 이용하여 표면염소이온 농도와 염소이온확산계수를 회귀분석을 통해 구할 수 있다(한 상훈, 2008).

$$
\begin{aligned}
& C_{d}=C_{o} {\left[1-\operatorname{erf}\left(\frac{x}{\sqrt{4 D_{d}}}\right)\right] } \\
& \text { 여기서, } C_{d}: \text { 염소이온농도 }\left(\mathrm{kg} / \mathrm{m}^{3}\right) \\
& C_{o}: \text { 표면염소이온농도 }\left(\mathrm{kg} / \mathrm{m}^{3}\right) \\
& x: \text { 표면으로부터 거리 }(\mathrm{m}) \\
& D_{d}: \text { 염소이온확산계수 }\left(\mathrm{m}^{2} / \mathrm{s}\right) \\
& t: \text { 재령 }(\mathrm{s}) \\
& e r f: \text { 오차함수(error function) }
\end{aligned}
$$

$$
\operatorname{erf}(z)=\frac{2}{\sqrt{\pi}} \int_{0}^{z} e^{-\xi^{2}} d \xi
$$

Fig. 8은 지역별, 수직 높이별 표면염소이온농도의 변화를 나 타내고 있다. 재령이 가장 오래된 마산항의 표면염소이온농도가 제일 크고 수직 높이별 염소이온농도의 차이도 크지 않다. 재령 10 년 정도인 동해항과 광양항의 시료들의 표면염소이온농도가 가장 작다. 즉, 재령이 클수록 표면염소이온농도가 큰 것을 알 수 있고 수직 높이별 표면염소이온농도는 재령이 경과하면 그 차 이가 줄어듬을 관찰할 수 있다. 


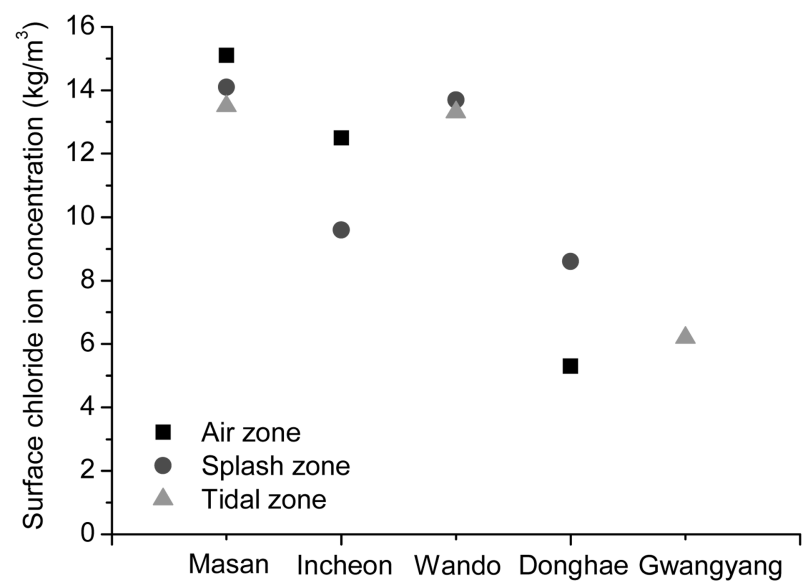

Fig. 8. Surface chloride ion concentration.

일본의 콘크리트표준시방서와 개정되기 전의 한국의 콘크리 트표준시방서에서는 수직높이에 관계없이 $13 \mathrm{~kg} / \mathrm{m}^{3}$ 의 표면염소 이온농도를 제시하고 있다. 현 연구의 실험결과 중 20 년 이상 시료들의 표면염소이온농도를 평균하면 $13.1 \mathrm{~kg} / \mathrm{m}^{3}$ 로 계산된다. 즉, 시방서의 제안값과 거의 유사함을 알 수 있다. 한편, 국내의 다른 연구자(정해문 등, 2005)는 서남해안의 간만대, 비말대, 해 상대기부의 표면염화물량은 $20.0,5.0,2.5 \mathrm{~kg} / \mathrm{m}^{3}$ 을 제시하고 있 고, 동해안은 비말대와 해상대기중에서 각각 13 과 $9.0 \mathrm{~kg} / \mathrm{m}^{3}$ 의 표면염화물량을 제안하고 있다. 따라서, 이에 대한 추가적인 연 구가 필요할 것으로 판단된다.

\section{3 염소이온확산계수}

앞에서 언급한 식 (1)을 이용하여 깊이별 염소이온농도 실험 결과를 회귀분석하면 표면염소이온농도 뿐만아니라 염소이온확 산계수를 구할 수 있다. Fig. 9(a)는 지역별, 수직 높이별 염소 이온농도의 변화를 나타내고 있다. 표면염소이온농도와는 달리 재령이 오래된 마산항이 염소이온확산계수가 가장 작고 상대적으 로 최근에 건설된 동해항과 광양항의 염소이온확산계수가 가장 크 다. 이것은 기존의 연구결과와도 일치하는 경향으로 Fig. 9(b) 에서는 재령에 따른 염소이온확산계수를 나타내고 있다. Bamforth
(1998)는 기존에 발표된 여러 데이터와 자신의 데이터를 종합하 여 Fig. 9(b)와 같은 재령과 염소이온확산계수의 상관관계를 제 시하였다. 실험에 의해서 구한 값들과는 절대값에서 조금 차이가 나지만, 재령에 따른 염소이온확산계수의 변화양상이 거의 유 사함을 관찰할 수 있다. 한편, Bamforth의 모델식과의 절대값 차이는 콘크리트배합에서의 차이에서 기인한 바가 크다고 사료 된다.

\section{4. 결 론}

항만구조물에서의 염소이온침투현상을 파악하기 위해서는 주 요 리모델링 대상항만에 대한 현장시료를 채취하고 이에 대한 내구성실험을 실시하였다. 질산은 변색법으로는 염소이온침투 깊이를 측정하였고, $\mathrm{ASTM}$ 과 RCT 기법을 이용하여 깊이별 염 소이온농도를 측정하였고 이를 바탕으로 지역별, 재령별 염소 이온침투현상을 파악하였다.

질산은 변색법에 의하면 동해항 비말대와 마산항의 간만대는 염소이온 침투깊이가 상당히 크다. 질산은 변색법에 의한 침투 깊이가 임계염소이온농도지점에 해당된다는 연구도 있으므로, 이러한 수준으로 염소이온이 침투된다면 철근부식의 문제가 발 생할 수 있음을 추정할 수 있다.

염소이온농도를 측정하는 두 시험법 중에서 간편법인 RCT 법은 ASTM법에 비해 상대적으로 작은 염소이온농도를 제시 한다. 따라서, RCT법을 사용할 때에는 시료에서 충분한 염소 이온의 추출이 가능하도록 해야하며, 실험데이타를 내구성설계에 사용할 때에도 주의가 필요할 것으로 판단된다.

코어시료의 깊이별 염소이온농도결과를 회기분석하여 표면염 소이온농도와 염소이온확산계수를 구하였다. 표면염소이온농도 는 재령이 오래된 마산항의 경우가 가장 큰 값을 나타내었고, 수직 높이별 표면염소이온농도의 변화는 크지 않았다. 또한, 실 험결과 중 20 년 이상 시료들의 표면염소이온농도를 평균하면 $13.1 \mathrm{~kg} / \mathrm{m}^{3}$ 로 계산되는데, 이것은 일본콘크리트표준시방서의 제 안값과 거의 유사하였다. 본 연구에서 구한 염소이온확산계수는 재령에 따라 감소하였는데, 이러한 경향성은 기존의 연구와 잘 일치하였다.

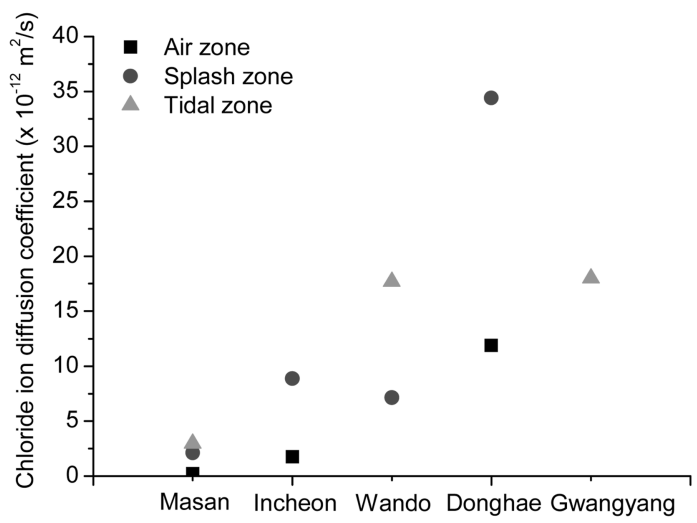

(a) Location

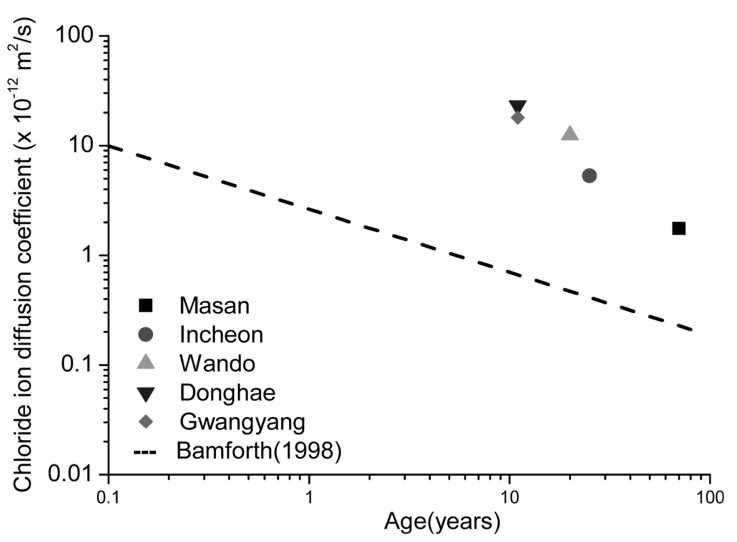

(b) Age

Fig. 9. Chloride ion diffusion coefficient. 


\section{감사의 글}

본 연구는 국토해양부가 출연하고 한국해양과학기술진흥원에 서 위탁시행한 항만리모델링 기반구축연구사업의 연구비 지원에 의해 수행되었습니다. 또한, 항만들에 대한 시료 채취를 도와 주신 (주)비앤티엔지니어링의 이상민 박사님과 최진강 부장님 및 내구성실험을 도와주신 강릉대학교 양은익 교수님에게 감사 드립니다.

\section{참고문헌}

김명유 (2010). 철근콘크리트 부재의 부식 저항성과 부식 상태 에 대한 평가, 박사논문.

박승범, 김도겸 (2000). 콘크리트 중의 염소이온 확산 특성에 관 한 실험적 연구. 한국콘크리트학회 논문집, 12(2), 33-44. 이상민, 이우철, 한상훈, 박우선 (2009). 복합열화를 고려한 해 양콘크리트의 잔존수명 평가방안. 한국해양과학기술협의회 공 동학술대회 논문집. 2218-2221.

정해문, 안태송, 이병덕 (2005). 국내 서남해안의 콘크리트 표 면염화물량 산정에 관한 연구. 한국콘크리트학회 봄학술대회 논문집, 173-176.

한상훈, 박우선, 김동현 (2003). 해양 콘크리트 구조물의 염소 이온 침투해석. 한국해안해양공학회지, 15(2), 71-79. 한상훈 (2008). Level II 수준에서의 항만 콘크리트 구조물의 내
구신뢰성 해석. 한국구조물진단학회, 9(7), 129-139.

한국콘크리트학회 (2009). 콘크리트표준시방서. 국토해양부제정. American Association of State Highway and Transportation Officials (1997). Standard Method of Test for Sampling and Testing for Chloride Ion in Concrete and Concrete Raw Materials (AASHTO T 260).

American Society for Testing and Materials. (2000). Standard test methods for chemical analysis of hydraulic cement (ASTM C 114).

Bamforth, P. B. (1992). Spreadsheet model for reinforcement corrosion in structures exposed to chlorides. In concrete under severe conditons, E \& FN Spon, Lodon.

Germann Instruments. (2010). Catalog NDT-2010: RCT and RCTW. Neville, A. M. (1995). Properties of concrete, Longman.

Otuki, N., Nagataki, S. and Nakashita, K. (1992). Evaluation of $\mathrm{AgNO}_{3}$ solution spray method for measurement of chloride penetration into hardened cementitious matrix materials. ACI material journal, 89(6), 587-592.

Val, D. V. and Trapper, D. V. (2008). Probabilistic evaluation of initiation time of chloride-induced corrosion. Reliability Engineering \& System Safety, 93, 364-372.

원고접수일: 2010년 9월 30일 수정본채택: 2010년 10월 6일 게재확정일: 2010년 11월 19일 